\title{
2919TE BESTUURSVERGADERTNG
}

GEHOUDKN 17 MART 1888.

Tegenwoordig de heeren Kern (Voorzitter), Kielstra (Ondervoorzitter), J. H. de Groot (Penningmeester), Humme, Bool, Martin, Snouek Hurgronje, Wilken, Niemann, Riedel en Wịnmalen (Secretaris).

De notulen van het verhandelde in de vorige vergadering worden voorgelezen en goedgekeurd, waarna eveneens mededeeling wordt gedaan van de aanteekeningen der laatst gehouden Algemeene jaarlijksche vergadering, welke voorloopig worden vastgesteld en zullen worden opgenomen in de eerstvolgende aflevering der Bijdragen.

De Voorzitter deelt mede, dat van de heeren Dr. L. W. G. de Roo en Prof. Dr. G. A. Wilken brieven zijn ontvangen, waarbij zij kennis geven de op hen uitgebrachte benoeming tot leden van het Bestuur te aanvaarden.

Ter vergadering tegenwoordig, worden zij voorts door den Voorzitter verwelkomd, die hun de behartiging van de belangen van het Instituut aanbeveelt, in de hoop tevens dat zij zullen willen medewerken ter bevordering van het doel der Vereeniging.

Aan de orde is de verkiezing van een Voorzitter, Ondervoorzitter, Penningmeester en Secretaris ingevolge art. 9 van het Reglement.

Uit de gehouden stemming blijkt dat ter vervulling dier verschillende betrekkingen respectievelijk worden herbenoemd de heeren Kern, Kielstra, de Groot en Wijnmalen, die, onder dankbetuiging, zich bereid verklaren opnieuw het hun opgedragen mandaat te aanvaarden.

Na mededeeling van de voornaamste ingekomen boekwerken, wordt bericht, dat zijn ingekomen: 
10. eene missieve van de Directie van de United States Geological Survey, te Washington, houdende dankbetuiging voor de ontvangst van de eerste aflevering van deel XXXVII der Bijdragen van het Instituut. Voor kennisgeving aangenomen.

20. eene missive van het Bestuur van de Société de Géographie, te Parijs, van den 28 Februari jl., waarin het eene opgave geeft van eenige leemten in de verzameling der Bijdragen en afzonderlijke Werken, die het Genootschap telkens van het Instituut mocht ontvangen, met verzoek het ontbrekende te willen aanvullen. In handen gesteld van den Secretaris, met opdracht, zoo mogelijk althans, aan het gedaan verzoek te voldoen, terwijl het Bestuurslid de Roo zich bereid verklaart zijne tusschenkomst te verleenen, waar het de aanvulliug geldt van de ontbrekende afleveringen van het Tijdschrift voor Indische taal-, land- en volkenkunde, welk orgaan verkeerdelijk door het Parijsche Genootschap wordt beschouwd als een der uitgaven van het Instituut.

30. missives van de hh. Jhr. mr. J. F. Alewijn, mr. G. H. Betz, J. W. van den Broek, A. Cochius, W. J. Derx, S. C. van Doesburgh, Prof. mr. H. L. Drucker, mr. W. Francis, mr. S. J. Hingst, dr. C. W. Janssen, A. H. Kiehl, A. M. Kollewijn Nz., mr. J. A. Levy, mr. A. Lind, G F. Lucardie, Prof. Mr. J. Oppenheim, W. L. de Petit, Prof. dr. A. Pierson, Jhr. mr. J. C. Reijnst, Jhr. J. H. P. von Schmidt auf Altenstadt, N. D. Schuurmans, J. A. Schröder, E. P. C. Sol, J. N. A. Baron Taets van Amerongen, G. C. C. Thierens, L. de Vlaming, C. E. Uhlenbeck, Mr. M. P. H. Wiercx, mr. O. J. E. Baron van Wassenaer van Catwijck en F. J. A. van Zijll de Jong, - allen houdende kennisgeving van de aanvaarding hunner benoeming tot.leden van het Instituut.

Voor kennisgeving aangenomen.

40. missives van de hh. F. Buttikofer, Dr. A. A. van Bemmelen, J. van Dam van Isselt en P. C. F. Snellen, waarbij zij, hoewel zij de benoeming tot leden van het Instituut op prijs stellen, echter om persoonlijke redenen zich genoopt gevoelen de op hen uitgebrachte keuze niet te aanvaarden.

Voor kennisgeving aangenomen.

50. eene missive van den heer mr. C. F. van Meuas, griffier bij 
het Hof van Justitie te Paramaribo, waarbij wordt bericht dat hij, gaarme de benoeming tot lid van het Instituut aanvaardende, tevens bereid is als vertegenwoordiger der Vereeniging in Suriname op te treden, met verzoek hem te zijner tijd te willen inlichten op welke wijze hij de belangen van het Institunt het meest zou kunnen behartigen, hetzij door zelf geo- en ethnografische en linguistische bijdragen te leveren of anderen tot de inzending daarvan op te wekken, hetzij door toezending van de voornaamste in de kolonie gedrukte stukken en werken, terwijl inmiddels de sedert 1 Januari $j 1$. verschenen nummers van een der aldaar verschijnende couranten worden aangeboden.

Den Secretaris wordt opgedragen de gevraagde inlichtingen te verstrekken.

60. eene missive van den heer F. II. J. Prive, te Solok, houdende bericht, dat de benoeming tot lid van het Institunt door hem wordt aanvaard. Voor kennisgeving aangenomen.

70. briefkaarten van Commissarissen uit Indië, van 13 Januari en 17 Februari jl., houdende mededeeling dat, met ingang van 1 Jan. ] 888, als leden van het Instituut zijn toegetreden de heeren mr. W. A. J. van Davelaar, leeraar aan het gymnasium Willem III te Batavia en L. Knappert, aspirant-controleur te Païnan (Sumatra's Westkust), met verzoek hun de edita over het loopende jaar te willen doen toezenden.

Voor kennisgeving aangenomen.

Ter tafel wordt gebracht een schrijven van Commissarissen uit Indië, dd. 25 Jan. jl. No B/154, waarbij wordt aangeboden: a. de rekening en verantwoording van hun geldelijk beheer over 1887 , sluitende met een kassaldo van $f 250.85^{5} ; b$. eene opgaaf van de leden die achterstallig zijn in de betaling hunner contributie, waarbij een paar toelichtende aanteekeningen; $c$. eene lijst van de Indische leden, met opgaaf van woonplaats, waaruit blijkt dat het Instituut in Indië 176 leden telt, waarvan 19 met verlof in Nederland en 4 in Nederland hunne contributie betalen, terwijl sedert nog als lid is toegetreden de heer Dr. H. J. Boelman te Djokdjakarta, onder mededeeling wijders, dat door gebruik te maken van de destijds door Cominissarissen gedane aanwijzing voorzeker het ledental in Indië nog voor anmerkelijke uitbreiding vatbaar zal zijn; $d$. eene 
lijst van de personen die van de ledenlijst zijn afgevoerd, ten getale van 9 ; en eindelijk e. eene lijst der in verantwoording zijnde boeken.

De Secretaris deelt mede, dat de Penningmeester met hem de aangeboden verantwoording heeft nagezien en in orde bevonden, waarom hij voorstelt daarop de goedkeuring van het Bestuur te verleenen, onder dankzegging aan Commissarissen voor hun geldelijk beheer; en wat voorts de overige door hen overgelegde bescheiden betreft, hem, Secretaris, te machtigen van den inhoud daarvan aanteekening te houden en Commissarissen de inlichtingen te verstrekken, welke hem in het belang hunner administratie noodig mochten voorkomen. Dienovereenkomstig wordt besloten.

Naar aanleiding eener mededeeling, in de vorige vergadering gedaan, rapporteert de Penningmeester, dat aan den heer Jhr. B. L. Teding van Berkhout wèl voor de vertaling van het eerste gedeelte van Bock's reisverhaal, doch niet voor die van het slot daarvan, dat $\mathrm{nu}$ is verschenen, honorarium is uitbetaald geworden. Na gedachtenwisseling wordt, overeenkomstig zijn voorstel, besloten het honorarium alsnog te voldoen en dit te stellen op f 12 per vel.

Onder herinnering aan de oproeping, door den heer P. Brooshooft te Samarang tot eenige belangstellenden hier te lande gericht ter behartiging van de Indische belangen, deelt de heer Kielstra mede, dat zich onlangs eenige heeren hebben vereenigd, die gaarne eerstdaags ter bespreking der zaak zouden willen samenkomen, waarom hij machtiging verzoekt voor die vergadering gebruik te mogen maken van de vergaderzaal van het Instituut.

Zonder beraadslaging wordt de gevraagde machtiging verleend.

Niets meer hierna aan de orde zijnde, wordt de vergadering door den Voorzitter gesloten. 